\title{
Assembly and Evolution of Gemini-Type Peptide Amphiphile with a Di-Lysine Spacer
}

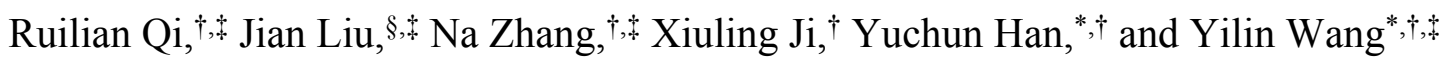

${ }^{\dagger}$ Key Laboratory of Colloid, Interface and Chemical Thermodynamics and \$Key Laboratory of Molecular Nanostructure and Nanotechnology, Beijing National Laboratory for Molecular Sciences (BNLMS), CAS Research/Education Center for Excellence in Molecular Sciences, Institute of Chemistry, Chinese Academy of Sciences, Beijing 100190, P. R. China. tUniversity of Chinese Academy of Sciences, Beijing 100049, P. R. China

\section{Table of Contents}

Figure S1 Time-dependent IR spectra

Page S2

Figure $\mathrm{S} 2 \mathrm{pH}$ titration curve

Page S2

Figure S3 UV absorbance change with time at $\mathrm{pH} 7.4$

Page S2

Figure S4 Cryo-TEM image at $\mathrm{pH} 7.4$ and $25{ }^{\circ} \mathrm{C}$

Page S3

Figure S5 Cryo-TEM image at $\mathrm{pH} 3.0$ and $50{ }^{\circ} \mathrm{C}$

Page S3

Figure S6 DSC thermograms at different concentrations

Page S3

Figure S7 DSC thermograms of different peptide amphiphiles

Page S4 


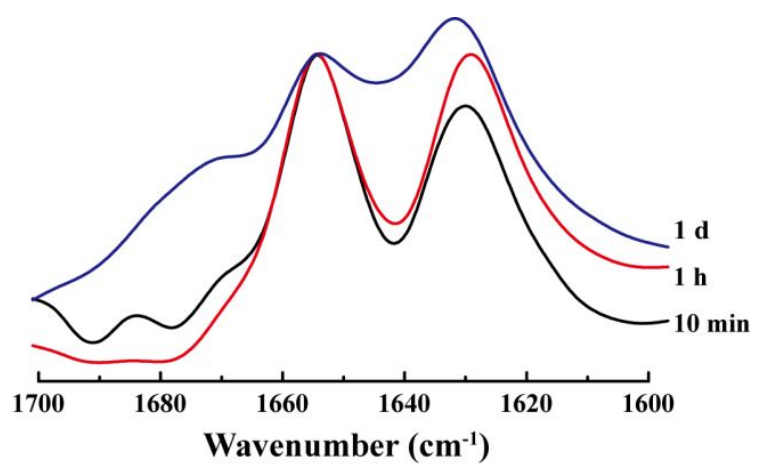

Figure S1. Time-dependent IR spectra of the dried 12-(Lys) $)_{2}-12$ samples. Three curves are normalized at $1655 \mathrm{~cm}^{-1}$.

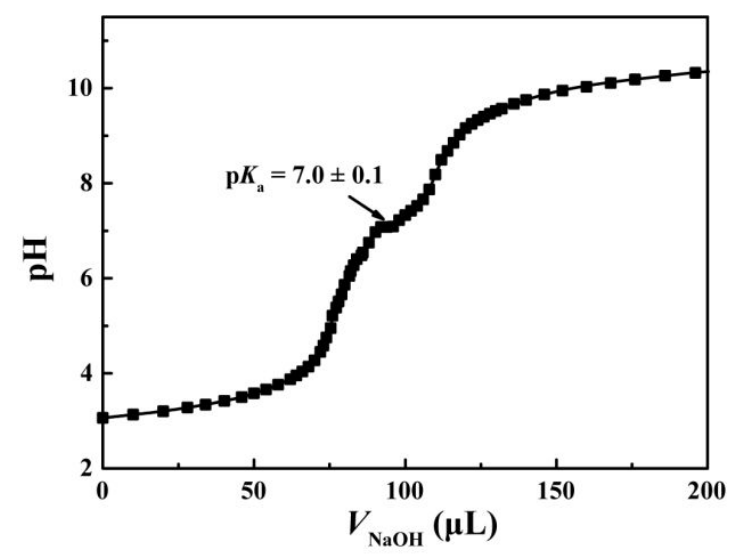

Figure S2. $\mathrm{pH}$ titration curve of $0.70 \mathrm{mM} 12-(\mathrm{Lys})_{2}-12$ solution at $25.0{ }^{\circ} \mathrm{C}$.

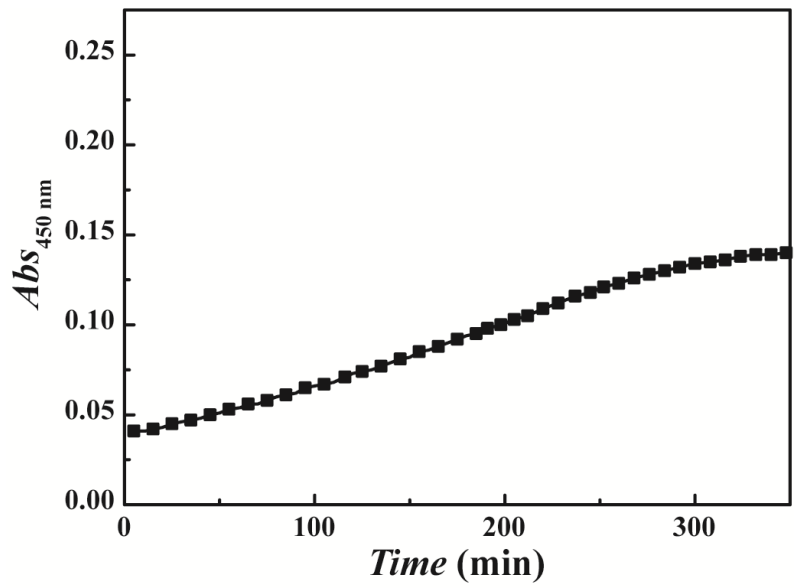

Figure S3. UV absorbance change with time of $0.70 \mathrm{mM} 12$-(Lys) $)_{2}-12$ solution at $\mathrm{pH} 7.4$ and 25.0 ${ }^{\circ} \mathrm{C}$. 


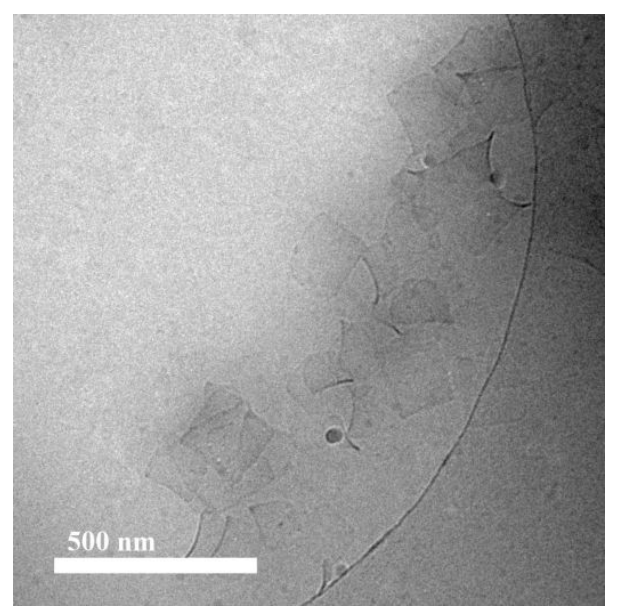

Figure S4. Cryo-TEM image of $0.70 \mathrm{mM} 12$-(Lys) $)_{2}-12$ solution at $\mathrm{pH} 7.4$ and $25.0{ }^{\circ} \mathrm{C}$.

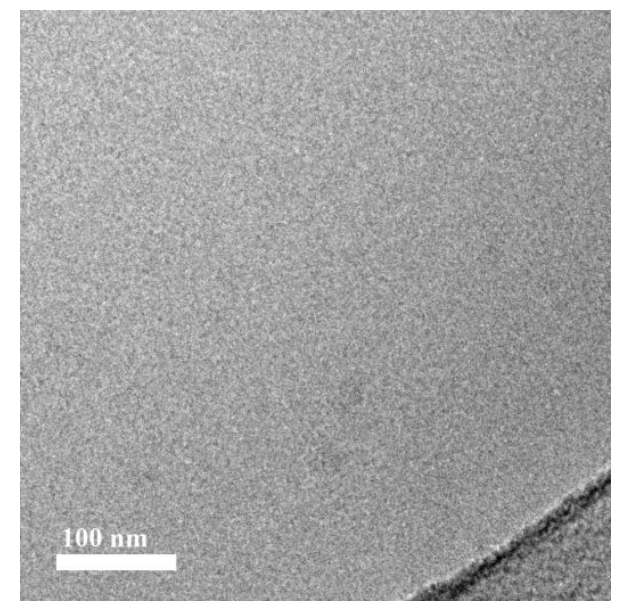

Figure S5. Cryo-TEM image of $0.70 \mathrm{mM} 12-(\text { Lys })_{2}-12$ solution at $\mathrm{pH} 3.0$ and $50.0{ }^{\circ} \mathrm{C}$.

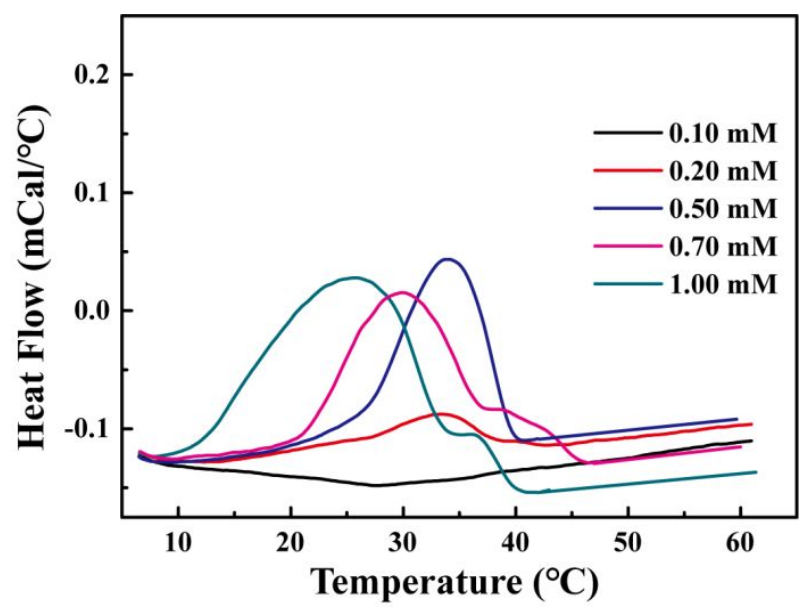

Figure S6. DSC thermograms of different concentrations of 12-(Lys) $)_{2}-12$ solutions at $\mathrm{pH} 3.0$. 


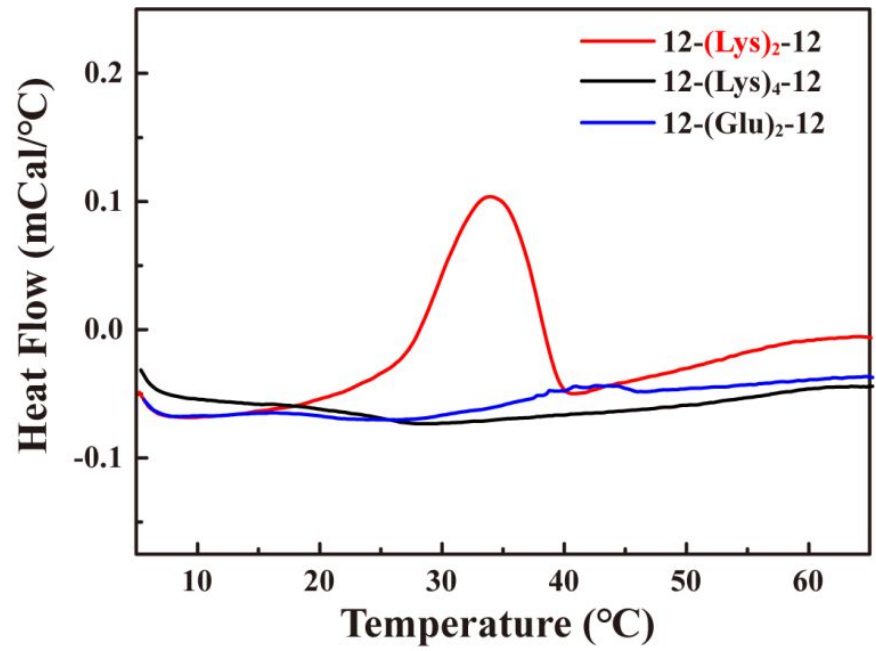

Figure S7. DSC thermograms of 12-(Lys) $)_{2}-12$ at $\mathrm{pH} 3.0$ (red line), 12-(Lys) $)_{4}-12$ at $\mathrm{pH} 3.0$ (black line) and $12-(\mathrm{Glu})_{2}-12$ at $\mathrm{pH} 11.0$ (blue line). The concentrations of these PAs used are $0.70 \mathrm{mM}$. 